\title{
STUDI NUMERIK PERILAKU PENGARUH TEGANGAN SISA PADA KOLOM BAJA KASTELA YANG DIBEBANI TEKAN AKSIAL
}

\author{
Novianty \\ ${ }^{1}$ Magister Teknik Sipil, Fakultas Teknik, Universitas Tarumanagara \\ Surel: hpf.pot@gmail.com
}

\begin{abstract}
In the field of construction, the development of science in particular to study the properties and behavior of steel components is needed to facilitate the planning of steel structures. The behavior of the steel components to be investigated is the effect of the residual stress on the castellated steel column burdened by axial pressure. The critical compressive strength of bending on the weak axis is examined with finite element method (FEM) to consider the effect of residual stress patterns and geometry of the castellate components. Three specimens were analyzed with various lengths and the profile used was the hexagonal castellate profile. The structure modeling is conditioned as such, so that it is a copy of the original condition. Analysis was carried out using Ansys v.18 Finite Element Method software and FEM result shows that the greater the slenderness ratio, the effect of the residual stress is lesser.
\end{abstract}

Keywords: hexagonal castella profile, bending of weak axis, residual stress, Ansys finite element method

\begin{abstract}
ABSTRAK
Dalam bidang konstruksi, pengembangan ilmu khususnya untuk mempelajari sifat -sifat dan perilaku komponen baja sangat diperlukan untuk mempermudah dalam perencanaan struktur baja. Perilaku komponen baja yang akan diteliti adalah pengaruh tegangan sisa pada kolom baja kastela yang dibebani tekan aksial. Gaya tekan kritis tekuk lentur pada sumbu lemah diteliti dengan finite element method (FEM) untuk mempertimbangkan pengaruh pola tegangan sisa dan geometri komponen kastela. Sebanyak tiga benda uji dianalisis dengan berbagai panjang dan profil yang digunakan adalah profil kastela heksagonal. Pemodelan struktur dikondisikan sedemikian rupa sehingga sama dengan kondisi aslinya. Analisis dilakukan dengan perangkat lunak metode elemen hingga Ansys v.18 dan hasil FEM menunjukkan bahwa semakin besar rasio kelangsingan maka pengaruh tegangan sisa semakin kecil.
\end{abstract}

Kata kunci: profil kastela heksagonal, tekuk lentur sumbu lemah, tegangan sisa, metode elemen hingga Ansys

\section{PENDAHULUAN}

Komponen baja berbentuk I mewakili elemen struktur dasar dalam mayoritas bangunan baja struktural. Pertimbangan praktis mungkin memerlukan beberapa komponen baja yang memiliki bukaan badan untuk pemasangan pipa dan saluran listrik. Bukaan badan tipikal yang biasa digunakan dalam struktur baja mencakup lubang heksagonal, lubang oktagonal dan lubang seluler. Dalam penelitian ini digunakan lubang heksagonal.

Komponen baja kastela biasanya diproduksi dengan melakukan pemotongan dan pengerjaan pengelasan kembali pada penampang komponen baja I hot-rolled. Seperti diilustrasikan pada gambar 1.1, pekerjaan ini akan mempengaruhi tegangan sisa yang ada dalam komponen baja yang dapat merugikan bagi tahanan tekuk. 


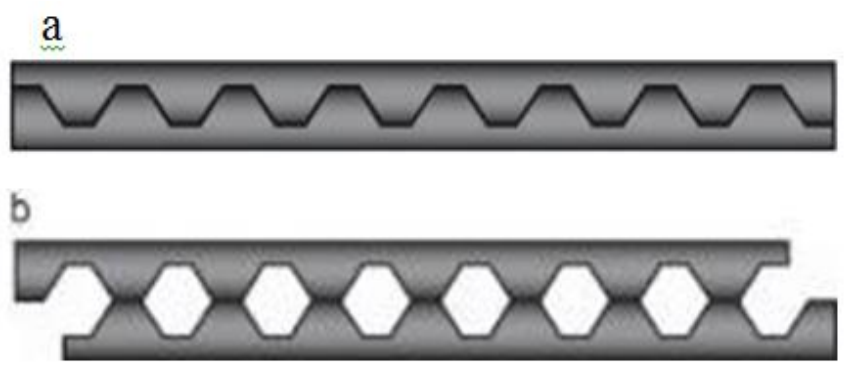

Gambar 1. Pabrikasi komponen baja dengan badan kastela heksagonal. (a) Potongan tipikal komponen kastela. (b) Penyusunan kembali komponen kastela

(Sumber: El-Sawy et al., 2009)

Dalam penelitian ini, pengaruh tegangan sisa pada kolom baja kastela yang dibebani tekan aksial akan diperiksa, dengan mempertimbangkan pengaruh modifikasi pola tegangan sisa dan geometri dimodifikasi pada komponen baja kastela. Oleh karena itu, beban tekuk kritikal pada komponen baja kastela yang ditumpu secara jepit bebas diselidiki secara numerikal.

Studi numerikal ini akan dilakukan dengan menggunakan perangkat lunak metode elemen hingga (Finite Element Method). Metode elemen hingga merupakan salah satu metode numerik yang dapat digunakan untuk menyelesaikan masalah struktural, termal dan elektromagnetik. Dalam metode ini seluruh masalah yang kompleks seperti variasi bentuk, kondisi batas dan beban diselesaikan dengan metode pendekatan. Karena keanekaragaman dan fleksibilitas sebagai perangkat analisis, metode ini mendapat perhatian dalam dunia teknik. Dalam penelitian ini perangkat lunak yang akan digunakan adalah Ansys.

Pemodelan numerik dan analisis kolom kastela yang dilakukan menggunakan Ansys, paket perangkat lunak elemen hingga yang bertujuan untuk menentukan beban tekuk elastis kritis dan mode terkait kegagalan kolom kastela tersebut. Geometri tipikal model kolom kastela ditunjukkan pada Gambar 1.2.

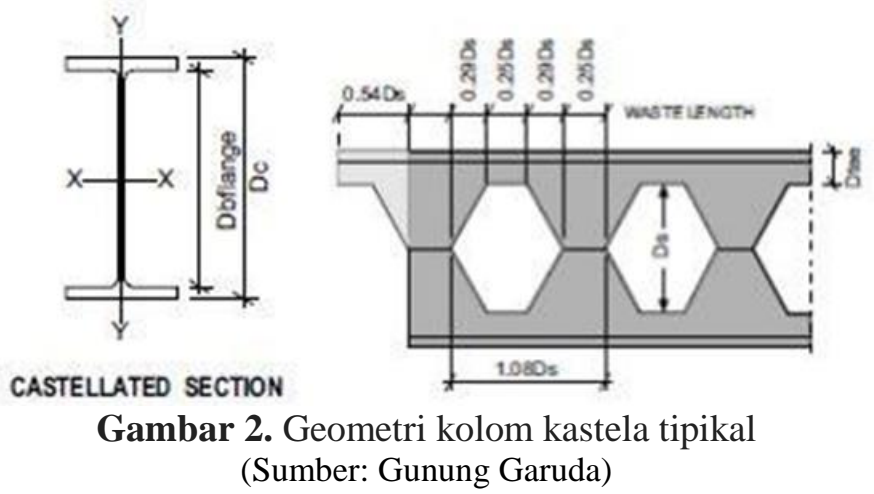

Pada tahun 1946, Column Research Council (CRC) merekomendasikan untuk mempelajari pengaruh tegangan sisa pada kekuatan komponen tekan (Beedle,1951). Dengan mempertimbangkan rekomendasi ini, penelitian di universitas Lehigh dimulai pada pengaruh tegangan sisa pada kekuatan kolom komponen I hot-rolled. Hasil penelitian ini dirangkum dalam Beedle dan Tall (1960). Lebih detail dapat ditemukan dalam Huber dan Beedle (1952), Huber dan Beedle (1954), Huber (1956) dan Beedle dan Huber (1957). 
Semua penelitian tersebut, mempelajari pengaruh tegangan sisa pada kolom tekuk. Dalam Galambos (1963), pengaruh merugikan dari tegangan sisa pada perilaku tekuk torsi lateral penampang balok I diilustrasikan dengan baik. Maka judul penelitian ini adalah "Pengaruh Tegangan Sisa Pada Kolom Baja Kastela yang Dibebani Tekan Aksial”.

Maksud dari penelitian ini adalah untuk membandingkan tekuk yang terjadi pada kolom kastela, akibat pengaruh tegangan sisa dan tanpa tegangan sisa. Dimensi profil baja yang digunakan dalam penelitian ini mengacu pada produksi Gunung Garuda, yaitu baja kastela heksagonal.

Adapun tujuan dari penelitian ini adalah sebagai berikut :

1. Mendapatkan hubungan beban tekuk kritikal - perpindahan yang mengarah pada sumbu lemah apabila dimensi perforasi heksagonal kolom kastela antara benda uji yang satu dengan yang lainnya dibuat berbeda-beda.

2. Memperoleh gaya tekan kritis tekuk lentur tanpa pengaruh tegangan sisa dan akibat pengaruh tegangan sisa yang terjadi pada kolom baja kastela.

Batasan masalah dalam tesis ini adalah: Profil yang digunakan terbuat dari baja gilas panas (hot rolled steel section), komponen baja kastela yang diteliti berupa tipe heksagonal, jenis tekuk kolom berupa inelastik, beban diberikan secara menerus, salah satu sisi komponen ditumpu jepit dan sisi lainnya bebas, hanya tekuk lentur lemah yang diperhatikan, analisis dilakukan dengan perangkat lunak elemen hingga yaitu Ansys versi 18, Data sampel penelitian komponen baja yang dibebani tekan aksial mengacu pada Gunung Garuda, Elemen yang digunakan dalam analisis adalah elemen solid.

\section{Tinjauan Pustaka}

\section{Desain Komponen Untuk Tekan}

Persamaan ini adalah sama dengan yang telah digunakan sejak 2005 AISC Spesifikasi untuk Baja Struktural Bangunan (AISC, 2005). Faktor resistensi, $\varphi$, meningkat 0,85-0,90 di 2005 AISC Spesifikasi, mengakui sejumlah besar dari penambahan kekuatan kolom analisis dan hasil tes, dikombinasikan dengan perubahan dalam praktek industri yang telah terjadi sejak kalibrasi asli dilakukan di tahun 1970-an dan 1980-an. Faktor panjang efektif (K), untuk menghitung kelangsingan komponen, rasio kelangsingan lebih baik tidak melampaui 200. 
$\lambda=K L / r$

Komponen tekuk lentur tidak langsing

$\phi_{c} P_{n}=F_{c r} A_{g}$

$\mathrm{F}_{\text {cr }}$ ditentukan sebagai berikut,
(a)
$K L / r \leq 4.71 \sqrt{E / F_{y}} \quad$ or $\quad F_{y} / F_{e} \leq 2.25 \quad ; \quad F_{c r}=\left(0.658^{F_{y} / F_{e}}\right) F_{y}$
(b) $K L / r>4.71 \sqrt{E / F_{y}}$ or $F_{y} / F_{e}>2.25 ; \quad F_{c r}=0.877 F_{e}$
$F_{e}=\pi^{2} E /(K L / r)^{2}$

Batang tekuk lentur langsing

$\phi_{c} P_{n}=F_{c r} A_{g}$

$\mathrm{F}_{\mathrm{cr}}$ ditentukan sebagai berikut,

$\begin{array}{ll}\text { (c) } K L / r \leq 4.71 \sqrt{E / Q F_{y}} \text { or } Q F_{y} / F_{e} \leq 2.25 ; & F_{c r}=\left(0.658^{Q F_{y} / F_{e}}\right) F_{y} \\ \text { (d) } K L / r>4.71 \sqrt{E / Q F_{y}} \text { or } Q F_{y} / F_{e}>2.25 ; & F_{c r}=0.877 F_{e} \\ & F_{e}=\pi^{2} E /(K L / r)^{2}\end{array}$

dengan,

$\mathrm{K}=$ Faktor panjang efektif

$\mathrm{L}=$ Panjang tak tertumpu lateral $(\mathrm{mm})$

$\mathrm{P}_{\mathrm{n}}=$ Kuat tekan nominal $(\mathrm{N})$

$\mathrm{r}=$ Radius girasi $(\mathrm{mm})$

$\phi_{\mathrm{c}}=$ Faktor reduksi tekan (0.9)

$\mathrm{A}_{\mathrm{g}}=$ Luas bruto $\left(\mathrm{mm}^{2}\right)$

$\mathrm{F}_{\mathrm{e}}=$ Tegangan Tekuk Elastis

$\mathrm{Q}=$ Faktor reduksi untuk elemen langsing

$\mathrm{F}_{\mathrm{cr}}=$ Tegangan kritis tekuk lentur yang didapat dari rasio kelangsingan $(\mathrm{MPa})$

\section{Tegangan Sisa}

Penelitian sistematis tentang efeknya tegangan sisa pada kekuatan kolom dimulai pada akhir 1940an di bawah bimbingan Komite Riset A dari Column Research Council (Osgood, 1951; Yang et al., 1952; Beedle and Tall, 1960). Karya ini berlanjut sampai awal 1970an dalam proyek penelitian ekstensif, terutama di Lehigh University (Kishima et al., 1969; McFalls and Tall, 1970; Alpsten dan Tall, 1970; Bjorhovde et al., 1972). Salah satu cara yang memungkinkan untuk membedakan kategori kekuatan kolom adalah dengan menggunakan konsep kurva beberapa kolom, seperti yang dikembangkan melalui penelitian di Lehigh University (Bjorhovde dan Tall, 1971; Bjorhovde, 1972) dan teori telah disediakan oleh studi di Eropa (Beer dan Schultz, 1970). Besar dan distribusi tegangan sisa dalam bentuk hot-rolled tergantung pada jenis penampang melintang, suhu, kondisi pendinginan, prosedur pelurusan, dan sifat material baja (Beedle and Tall, 1960). Contoh distribusi tegangan sisa pada gambar 2.1.

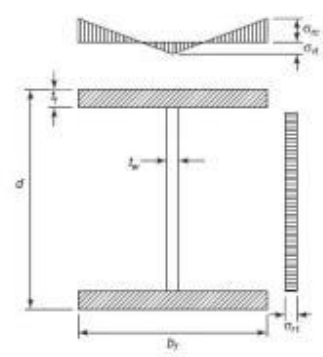

Gambar 3. Pola tegangan sisa

(Sumber: Galambos and Surovek, 2008) 


\section{Finite Element Method (FEM)}

Metode elemen hingga atau FEM merupakan metode yang dapat digunakan untuk memperoleh solusi numerik dari berbagai permasalahan mekanika struktur dan non-struktural. Metode ini adalah metode pendekatan yang mengacu pada displacement approach. Metode ini dianggap cukup memadai untuk menyelesaikan berbagai permasalahan mekanika dengan tingkat ketelitian dan toleransi penyimpangan yang dapat diterima oleh para ahli. Bila suatu elemen struktur dibagi-bagi menjadi beberapa bagian yang lebih kecil, maka bagian-bagian kecil ini disebut elemen hingga.Masing-masing elemen hingga saling terhubung pada titik-titik yang disebut nodal.Dinamakan elemen hingga karena ukuran elemen kecil ini berhingga (bukannya kecil tidak berhingga) dan umumnya memiliki bentuk geometri yang lebih sederhana dibandingkan dengan bentuk elemen strukturnya.

Dengan demikian, dalam FEM bukanlah memecahakan permasalahan elemen struktur secara keseluruhan dalam satu kali operasi, melainkan membuat formulasi persamaan untuk masingmasing elemen hingga, kemudian menggabungkannya untuk memperoleh solusi dari elemen strukturnya. Secara singkat, solusi dari permasalahan struktur yang dimaksud adalah menghitung besarnya perpindahan dan tegangan yang dialami struktur akibat adanya beban yang bekerja (Logan, 2007). Keakuratan dari hasil FEM sangat bergantung pada elemen yang digunakan, baik dari jenis elemen, bentuk elemen, dan cara melakukan diskritisasi elemen. Tiap jenis elemen memiliki degress of freedom (d.o.f.) yang berbeda-beda sehingga penentuan jenis elemen dapat disesuaikan dengan kebutuhan struktur yang akan dianalisis. (Cook et al., 2002). Meskipun jenis elemen yang digunakan sudah sesuai, namun apabila bentuk elemennya buruk maka hasil analisis menjadi tidak akurat. Bentuk elemen yang buruk dikenal dengan istilah distorted elements atau elemen yang terdistorsi.

\section{METODE PENELITIAN}

Pemilihan ukuran profil benda uji dalam penelitian ini mengacu pada profil baja Gunung Garuda.

Data Material yang digunakan dalam penelitian ini adalah sebagai berikut:

$\begin{array}{llll}\text { Densitas } & : 7850 \mathrm{~kg} / \mathrm{m}^{3} & \text { Poisson's ratio } & : 0,3 \\ \text { Modulus elastisitas } & : 200.000 \mathrm{MPa} & \text { Tegangan leleh } & : 240 \mathrm{MPa}\end{array}$

Kolom baja kastela yang tidak berlubang dengan tegangan sisa memiliki pola distribusi tegangan sisa yang mengacu pada Galambos dan Surovek (2008) dengan tegangan leleh tekan, $\sigma_{r c}=0.3 \mathrm{~F}_{\mathrm{y}}$ dan tegangan leleh tarik, $\sigma_{r t}=\frac{\sigma_{r c}}{1+\frac{d t_{w}}{b_{f} t_{f}}\left(1-\frac{2 t_{f}}{d}\right)}$. Dalam penelitian ini nilai tersebut diinput pada material tegangan leleh tekan dan tegangan leleh tarik. Pada baja kastela yang berlubang dengan tegangan sisa, tegangan sisa hanya ada disayap penampang baja dengan tegangan leleh tekan $\sigma_{r c}$ $=0.3 \mathrm{~F}_{\mathrm{y}}$ dan tegangan leleh tarik $\sigma_{r t}=0.3 \mathrm{~F}_{\mathrm{y}}$. Dalam penelitian ini, profil benda uji yang dianalisis secara FEM dilakukan terhadap tiga benda uji dengan profil baja kastela heksagonal yang dapat dilihat pada Gambar 3.1 dan Tabel 3.1 

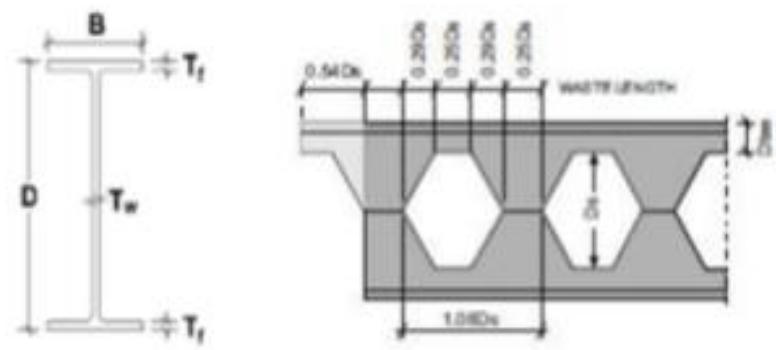

Gambar 4. Parameter kolom kastela heksagonal

(Sumber: Gunung Garuda)

Keterangan :

$\mathrm{B}=$ Lebar sayap $(\mathrm{mm})$

$\mathrm{D}_{\mathrm{s}}=$ Tinggi lubang kastela $(\mathrm{mm})$

$\mathrm{D}=$ Tinggi profil $(\mathrm{mm})$

$\mathrm{D}_{\text {tee }}=$ Tinggi tee Kastela $(\mathrm{mm})$

$\mathrm{T}_{\mathrm{w}}=$ Tebal badan $(\mathrm{mm})$

$\mathrm{L}=$ Panjang kolom kastela (mm)

$\mathrm{T}_{\mathrm{f}}=$ Tebal sayap $(\mathrm{mm})$

Tabel 1. Dimensi tiga profil benda uji yang dianalisis numerik

\begin{tabular}{cccccccc}
\hline No. & Benda Uji & $\mathbf{D}(\mathbf{m m})$ & $\mathbf{B}(\mathbf{m m})$ & $\mathbf{T}_{\mathbf{w}}(\mathbf{m m})$ & $\mathbf{T}_{\mathbf{f}}(\mathbf{m m})$ & $\mathbf{D}_{\mathbf{s}}(\mathbf{m m})$ & $\mathbf{D}_{\text {tee }}(\mathbf{m m})$ \\
\hline 1 & $375 \times 125$ & 375 & 125 & 6 & 9 & 254 & 60.5 \\
\hline 2 & $450 \times 150$ & 450 & 150 & 6,5 & 9 & 305 & 72,5 \\
\hline 3 & $525 \times 175$ & 525 & 175 & 7 & 11 & 354 & 85,5 \\
\hline \multicolumn{1}{r}{} & & & & \multicolumn{3}{c}{ (Sumber: Gunung Garuda) }
\end{tabular}

Elemen yang digunakan dalam analisis adalah Quadratic Tetrahedron elemen (solid 187). Karena analisis dilakukan secara 3D, dipilih elemen solid sehingga komponen baja bisa dibuat lubang yang berbentuk heksagonal dan dapat mempresentasikan perilaku tekuk pada setiap titik nodalnya.

Untuk semua kasus masing-masing type kolom kastela terdiri dari 5 jenis panjang yang berbeda. Benda uji 1 terdiri dari 886mm, 1160mm, 1435mm, 1709mm, 1983mm. Benda uji 2 terdiri dari $1065 \mathrm{~mm}, 1400 \mathrm{~mm}, 1723 \mathrm{~mm}, 2050 \mathrm{~mm}, 2400 \mathrm{~mm}$. Benda uji 3 terdiri dari $1235 \mathrm{~mm}, 1617 \mathrm{~mm}$, 2000mm, 2382mm, 2765mm. Pada Gambar 3.2 menunjukan tipikal jaring elemen yang digunakan dalam analisis. Pada kolom baja ditumpu jepit pada salah satu ujungnya yang diberi simbol huruf B dan salah satu ujungnya bebas diberi beban terpusat pada arah sumbu lemah komponen baja, yang diberi simbol huruf A tertampil pada Gambar 3.3
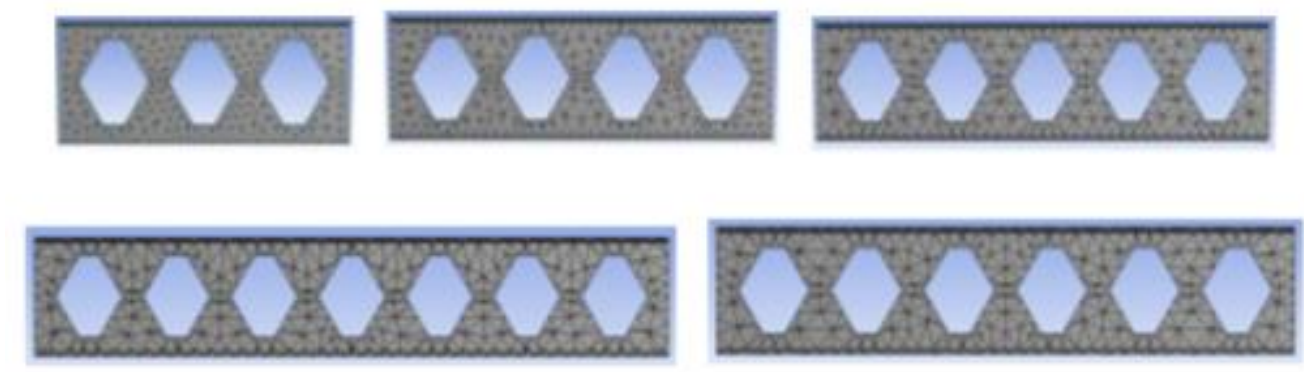

Gambar 5. Permodelan pada perangkat lunak Ansys 

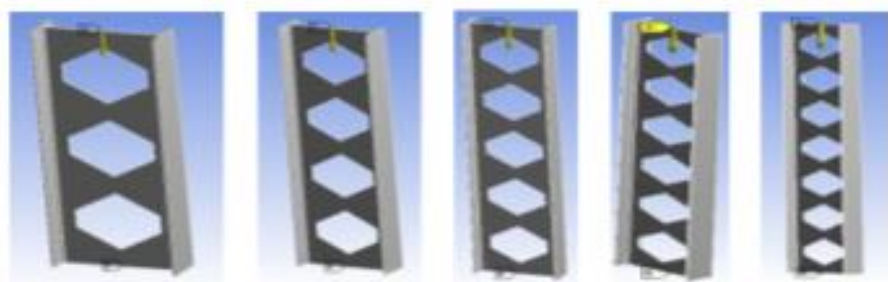

\section{Gambar 6. Komponen baja tertumpu jepit-bebas dan diberi beban terpusat}

Boundary conditions ditentukan sedemikian rupa sehingga analisis dapat mewakili kondisi sebenarnya. Untuk menganalisis komponen baja yang dibebani tekan aksial secara nonlinier terlebih dahulu menentukan ketidaksempurnaan awal atau geometri awal. Dalam penelitian ini mode tekuk yang pertama pada analisis secara linier yang diambil kemudian amplitudo komponen baja diambil nilai sebesar L/2000 yang diletakan pada posisi ujung bebas. Setelah itu diberi beban yang secara terus menerus pada ujung bebas sumbu lemah komponen baja hingga baja mengalami tekuk. Hal ini yang dianalisis secara nonlinier. Pada komponen baja dengan tegangan sisa, prosesnya sama seperti yang disebutkan diatas hanya ditambah tegangan sisanya pada komponen baja tersebut. Nilai tegangan sisa dapat dimasukan dimaterial pada program ansys dan besarnya nilai tegangan sisa dalam penelitian ini mengacu pada Galambos dan Surovek (2008).

Pada penelitian ini, diperhitungkan pengaruh material non-linearity dan geometry non-linearity. Material dalam kondisi elastis sampai titik leleh $F_{y}$. Strain hardening tidak diperhitungkan dalam penelitian ini.

\section{HASIL PENELITIAN}

\section{Hubungan Beban-Perpindahan Kolom yang Diberi Beban Tekan}

Tiga benda uji dengan berbagai panjang dipilih untuk dianalisis secara numerik. Analisis ini bertujuan untuk mendapatkan hubungan beban - perpindahan pada area yang diberi beban dan kemudian hasilnya akan dibandingkan antar kastela heksagonal yang dianggap solid, kastela heksagonal tanpa tegangan sisa, dan kastela heksagonal dengan tegangan sisa.

\section{Hasil FEM}

Berikut merupakan kurva beban-perpindahan dari salah satu tiga benda uji yaitu $375 \times 125$ disajikan pada gambar 4.1 - gambar 4.3 dan nilai beban-perpindahan dapat dilihat pada tabel 4.1- tabel 4.3. Kurva tegangan kritis tekuk lentur benda uji 1 sampai dengan benda uji 3 dapat dilihat pada gambar 4.4.
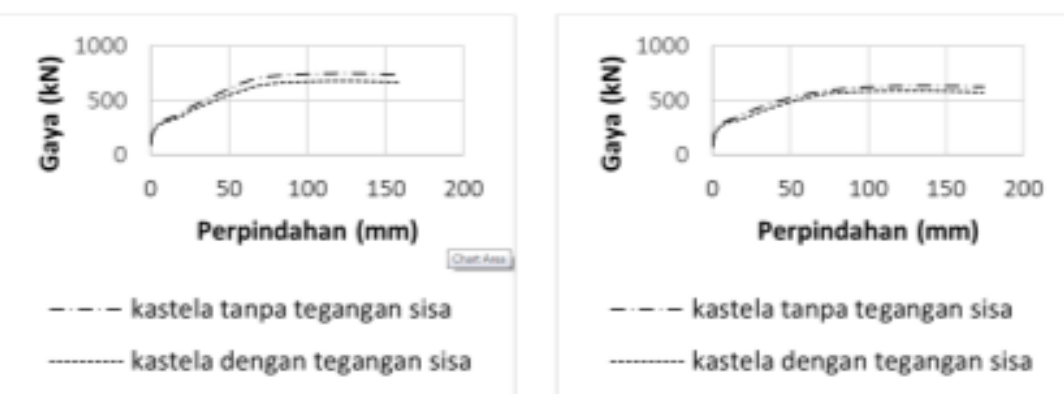

Gambar 7. Kurva beban - perpindahan untuk benda uji 1 dengan $\mathrm{L}=886 \mathrm{~mm}$ dan $\mathrm{L}=1160 \mathrm{~mm}$ (Sumber: hasil olah data) 

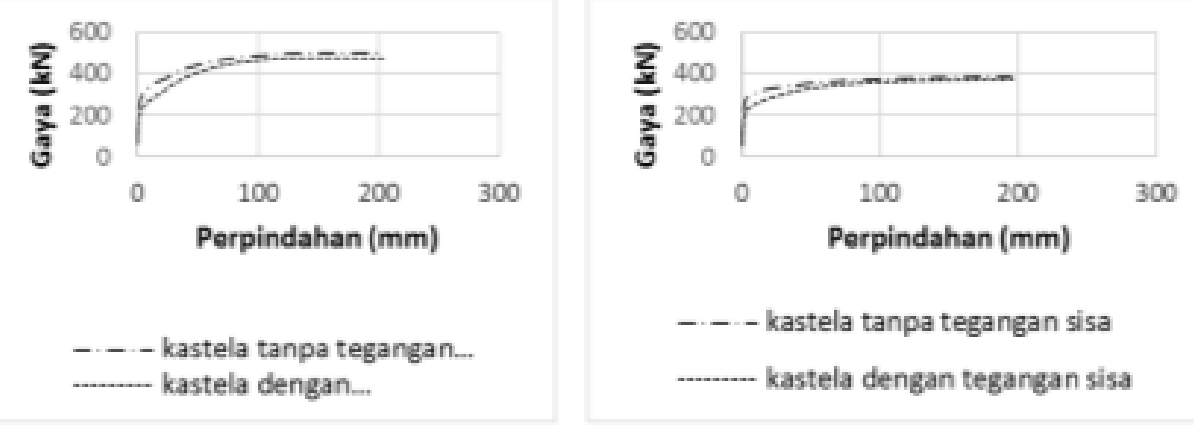

Gambar 8. Kurva beban - perpindahan untuk benda uji 1 dengan $\mathrm{L}=1435 \mathrm{~mm}$ dan $\mathrm{L}=1709 \mathrm{~mm}$ (Sumber: hasil olah data)

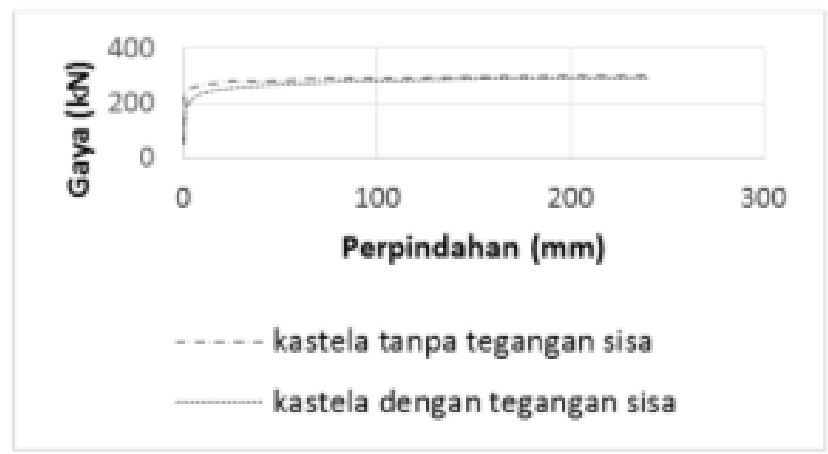

Gambar 9. Kurva beban - perpindahan untuk benda uji 1 dengan $\mathrm{L}=1983 \mathrm{~mm}$ (Sumber: hasil olah data)

Tabel 2. Nilai beban - perpindahan untuk beban uji 1

\begin{tabular}{cccccc}
\hline \multirow{2}{*}{ No } & $\begin{array}{c}\text { Panjang Kastela } \\
(\mathrm{mm})\end{array}$ & \multicolumn{2}{c}{ Kastela tanpa Tegangan Sisa } & \multicolumn{2}{c}{ Kastela dengan Tegangan Sisa } \\
\cline { 2 - 5 } & 886 & $\begin{array}{c}\text { Pu ultimate } \\
(\mathrm{kN})\end{array}$ & $\begin{array}{c}\text { Perpindahan } \\
(\mathrm{mm})\end{array}$ & $\begin{array}{c}\text { Pu Ultimate } \\
(\mathrm{kN})\end{array}$ & $\begin{array}{c}\text { Perpindahan } \\
(\mathrm{mm})\end{array}$ \\
\hline 1 & 751.7 & 123.45 & 710.24 & 123.7 \\
\hline 2 & 1160 & 636.55 & 135.39 & 591.92 & 127.96 \\
\hline 3 & 1435 & 501.02 & 198.7 & 471.65 & 201.76 \\
\hline 4 & 1709 & 385.07 & 212.34 & 372.83 & 213.43 \\
\hline 5 & 1983 & 299.08 & 222.52 & 292.1 & 240.22 \\
\hline
\end{tabular}

Tabel 3. Nilai beban - perpindahan untuk beban uji 2

\begin{tabular}{|c|c|c|c|c|c|}
\hline \multirow[b]{2}{*}{ No } & \multirow[b]{2}{*}{$\begin{array}{c}\text { Panjang Kastela } \\
(\mathrm{mm})\end{array}$} & \multicolumn{2}{|c|}{ Kastela tanpa Tegangan Sisa } & \multicolumn{2}{|c|}{ Kastela dengan Tegangan Sisa } \\
\hline & & $\begin{array}{l}\text { Pu ultimate } \\
(\mathrm{kN})\end{array}$ & $\begin{array}{l}\text { Perpindahan } \\
\text { (mm) }\end{array}$ & $\begin{array}{c}\text { Pu Ultimate } \\
(\mathrm{kN})\end{array}$ & $\begin{array}{l}\text { Perpindahan } \\
(\mathrm{mm})\end{array}$ \\
\hline 1 & 1065 & 950.56 & 163.18 & 912.79 & 163.4 \\
\hline 2 & 1400 & 785.73 & 183.78 & 748.71 & 162.53 \\
\hline 3 & 1723 & 603.82 & 220.17 & 576.83 & 224.34 \\
\hline 4 & 2050 & 466.19 & 257.27 & 452.2 & 259.17 \\
\hline 5 & 2400 & 367.013 & 271.46 & 363.49 & 274.71 \\
\hline
\end{tabular}

(Sumber: hasil olah data) 
Tabel 4. Nilai beban - perpindahan untuk beban uji 3

\begin{tabular}{cccccc|}
\hline \multirow{2}{*}{ No } & $\begin{array}{c}\text { Panjang Kastela } \\
(\mathrm{mm})\end{array}$ & \multicolumn{2}{c|}{ Kastela tanpa Tegangan Sisa } & \multicolumn{2}{c|}{ Kastela dengan Tegangan Sisa } \\
\cline { 2 - 6 } & 1235 & $\begin{array}{c}\text { Pu ultimate } \\
(\mathrm{kN})\end{array}$ & $\begin{array}{c}\text { Perpindahan } \\
(\mathrm{mm})\end{array}$ & $\begin{array}{c}\text { Pu Ultimate } \\
(\mathrm{kN})\end{array}$ & $\begin{array}{c}\text { Perpindahan } \\
(\mathrm{mm})\end{array}$ \\
\hline 1 & 1259.5 & 178 & 1188.8 & 178.31 \\
\hline 2 & 1400 & 785.73 & 183.78 & 748.71 & 162.53 \\
\hline 3 & 1723 & 603.82 & 220.17 & 576.83 & 224.34 \\
\hline 4 & 2050 & 466.19 & 257.27 & 452.2 & 259.17 \\
\hline 5 & 2400 & 367.013 & 271.46 & 363.49 & 274.71 \\
\hline
\end{tabular}

(Sumber: hasil olah data)

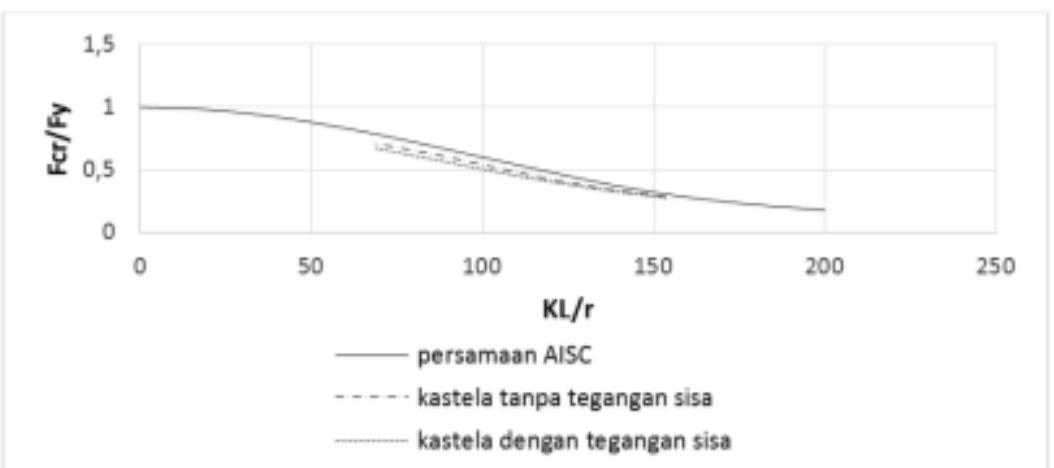

Gambar 10. Kurva tegangan kritis tekuk lentur benda uji 1

Pada gambar 4.6 kurva kolom, kurva persamaan AISC dengan garis utuh merupakan hasil analisis batang tekan kastela yang dianggap solid. Pada kurva garis titik garis merupakan hasil FEM batang tekan kastela tanpa tegangan sisa, sedangkan pada kurva garis putus-putus merupakan hasil FEM batang tekan kastela dengan tegangan sisa. Untuk sumbu vertikal, Fcr yang digunakan berupa luas batang tekan kastela yang dianggap solid begitu pula pada sumbu horizontal $r$ yang digunakan berupa luas dan momen inersia batang tekan kastela yang dianggap solid.

\section{Perbandingan Gaya Tekan Kritis Tekuk Lentur Hasil FEM}

Dalam (Beedle, 1951) percobaan menunjukkan bahwa tegangan sisa memiliki efek yang merugikan pada kapasitas batang tekan. Hasil eksperimen tegangan sisa pada bentuk hot-rolled wide-flange (Batterman dan Johnston, 1967) dan (Bjorhovde, 1972) menunjukkan dengan jelas bahwa pengaruh tegangan sisa pada kolom yang diberi tekan aksial, memberikan efek yang sedikit pada kolom yang sangat langsing.

Hasil penelitian numerik sama dengan hasil eksperimen di atas dengan menunjukkan bahwa gaya tekan kritis tekuk lentur pada kastela dengan tegangan sisa lebih kecil dibandingkan pada kastela tanpa tegangan sisa. Ini menunjukkan bahwa semakin besarnya $\mathrm{kl} / \mathrm{r}$, pengaruh tegangan sisa semakin mengecil. Perbandingan gaya tekan kritis tekuk lentur dapat dilihat pada tabel 4.4 dan tabel 4.5. Perbandingan ketiga penampang baja kastela tersebut berupa:

Tabel 5. Perbandingan gaya tekan kritis tekuk lentur pada $\mathrm{k} l / \mathbf{r}=70$

(Sumber: hasil olah data)

\begin{tabular}{ccc}
\hline $\begin{array}{c}\text { Beban } \\
\text { uji }\end{array}$ & $\begin{array}{c}\text { Gaya tekan kritis tekuk } \\
\text { lentur }\end{array}$ & Perbedaan \\
\hline
\end{tabular}




\begin{tabular}{lccc}
\hline & $\begin{array}{c}\text { Kastela yang } \\
\text { dianggap solid } \\
\text { dengan } \\
\text { tegangan sisa } \\
(\mathrm{kN})\end{array}$ & $\begin{array}{c}\text { Kastela } \\
\text { dengan } \\
\text { tegangan } \\
\text { sisa }(\mathrm{kN})\end{array}$ & \\
\hline $375 \times 125$ & 819,35 & 702,058 & $14,32 \%$ \\
\hline $450 \times 150$ & 1027,545 & 912,790 & $11,37 \%$ \\
\hline $525 \times 175$ & 1375,098 & 1164,859 & $16,29 \%$ \\
\hline
\end{tabular}

\begin{tabular}{cccc}
\hline \multirow{3}{*}{ Beban uji } & $\begin{array}{c}\text { Gaya tekan kritis } \\
\text { tekuk lentur }\end{array}$ & \\
\cline { 2 - 3 } & $\begin{array}{c}\text { Kastela } \\
\text { tanpa } \\
\text { tegangan } \\
\text { sisa }(\mathrm{kN})\end{array}$ & $\begin{array}{c}\text { Kastela } \\
\text { dengan } \\
\text { tegangan } \\
\text { sisa }(\mathrm{kN})\end{array}$ & \\
\hline $375 \times 125$ & 743,737 & 702,058 & $5,6 \%$ \\
\hline $450 \times 150$ & 950,56 & 912,790 & $3,97 \%$ \\
\hline $525 \times 175$ & 1232,849 & 1164,859 & $5,51 \%$ \\
\hline
\end{tabular}

Tabel 6. Perbandingan gaya tekan kritis tekuk lentur pada $\mathbf{k l} / \mathbf{r}=150$

(Sumber: hasil olah data)

\begin{tabular}{cccc}
\hline \multirow{4}{*}{$\begin{array}{c}\text { Gaya tekan kritis tekuk } \\
\text { Beban } \\
\text { uji }\end{array}$} & $\begin{array}{c}\text { Kastela yang } \\
\text { dianggap solid } \\
\text { dengan } \\
\text { tegangan sisa } \\
(\mathrm{kN})\end{array}$ & $\begin{array}{c}\text { Kastela } \\
\text { dengan } \\
\text { tegangan } \\
\text { sisa }(\mathrm{kN})\end{array}$ & $\begin{array}{c}\text { Perbeda } \\
\text { an }\end{array}$ \\
\hline $375 \times 125$ & 819,35 & 702,058 & $10,32 \%$ \\
\hline $450 \times 150$ & 429,472 & 395,1 & $8 \%$ \\
\hline $525 \times 175$ & 560,196 & 476,386 & $14,96 \%$ \\
\hline
\end{tabular}

\begin{tabular}{cccc}
\hline & \multicolumn{3}{c|}{ Gaya tekan kritis tekuk } \\
lentur \\
\cline { 2 - 3 } $\begin{array}{c}\text { Beban } \\
\text { uji }\end{array}$ & $\begin{array}{c}\text { Kastela yang } \\
\text { dianggap solid } \\
\text { dengan } \\
\text { tegangan sisa } \\
(\mathrm{kN})\end{array}$ & $\begin{array}{c}\text { Kastela } \\
\text { dengan } \\
\text { tegangan } \\
\text { sisa }(\mathrm{kN})\end{array}$ & \\
\hline $375 \times 125$ & 743,737 & 702,058 & $2,5 \%$ \\
\hline $450 \times 150$ & 402,354 & 395,1 & $1,8 \%$ \\
\hline $525 \times 175$ & 488,581 & 476,386 & $2,5 \%$ \\
\hline
\end{tabular}

Dari hasil perbandingan diatas diambil nilai yang tertinggi yaitu :

- Pada kl/r = 70 : Perbandingan antara kastela yang dianggap solid dengan tegangan sisa dan kastela dengan tegangan sisa sebesar 16,29\%. Perbandingan antara kastela tanpa tegangan sisa dan kastela dengan tegangan sisa sebesar 5,6\%.

- Pada kl/r = 150 :Perbandingan antara kastela yang dianggap solid dengan tegangan sisa dan kastela dengan tegangan sisa sebesar 14,96\%. Perbandingan antara kastela tanpa tegangan sisa dan kastela dengan tegangan sisa sebesar 2,5\%.

\section{KESIMPULAN}

\section{Kesimpulan}

Dari hasil penelitian ketiga benda uji yaitu kastela 375x125, 450x150, dan 525x175 dengan berbagai panjang ditampilkan kurva beban aksial - perpindahan yang mengarah pada sumbu lemah. Dari kurva kolom didapatkan gaya tekan kritis tekuk lentur pada kastela dengan tegangan sisa lebih kecil dibandingkan pada kastela tanpa tegangan sisa. Disimpulkan bahwa tegangan sisa memberi efek yang merugikan pada kapasitas kolom. Seperti yang diharapkan, pada kolom yang sangat langsing tegangan sisa memiliki efek yang sedikit pada kapasitas kolom. Dari kurva kolom dapat dilihat perbandingan antara kastela yang dianggap solid dengan tegangan sisa dan kastela dengan tegangan sisa pada $\mathrm{kL} / \mathrm{r}=70$ memiliki perbedaan sebesar $16,29 \%$ dan pada $\mathrm{KL} / \mathrm{r}=150$ memiliki perbedaan sebesar $14,96 \%$. Perbandingan antara kastela tanpa tegangan sisa dan kastela dengan tegangan sisa pada $\mathrm{kL} / \mathrm{r}=70$ memiliki perbedaan sebesar 5,6\% dan pada $\mathrm{KL} / \mathrm{r}=150$ memiliki perbedaan sebesar $2.5 \%$. Nilai $\mathrm{r}$ yang digunakan berupa luas dan momen inersia batang tekan kastela yang dianggap solid. Berarti, semakin besar KL/r, maka pengaruh tegangan sisa semakin kecil sehingga kastela dengan tegangan sisa seperti ini memiliki kapasitas mendekati kastela tanpa tegangan sisa.

Untuk desain dengan $\mathrm{KL} / \mathrm{r}$ yang lebih besar dari 70 dapat digunakan rumus AISC dengan mengasumsikan batang tekan berupa prismatis yang dikurangi sebesar 16,29\%. Sedangkan untuk 
desain kastela yang memperhitungkan tegangan sisa dengan $\mathrm{KL} / \mathrm{r}$ yang lebih besar dari 70 dikurangi sebesar $5,6 \%$.

\section{Saran}

Penelitian ini tidak dilakukan di laboratorium, hanya menggunakan satu pola tegangan sisa dengan nilai maximum $30 \%$ dari Fy. Untuk itu, penulis menyarankan agar dapat dilakukan studi lebih lanjut lagi mengenai perilaku kolom tekuk lentur di laboratorium, menggunakan pola tegangan sisa lainnya, maupun menggunakan nilai maximum tegangan sisa lainnya.

\section{REFERENSI}

American Institute of Steel Construction. Specification for Structural steel Building (AISC36005). Chicago : AISC, Inc., 2005.

American Institute of Steel Construction. Specification for Structural steel Building (AISC36016). Chicago : AISC, Inc., 2016.

Alpsten, G. A., and Tall, L. (1970) "Residual Stresses in Heavy Welded Shapes," Weld. J., Vol. 49, No. 3, pp. 93-105.

Beedle, L. S. (1951) Proposal Pilot program on the influence of residual stress on column strength. Fritz Laboratory Reports, paper 1501.

Beedle, L. S. and Tall, L. (1960) Basic column strength. Journal of the Structural Division, 86(7):139-173.

Beedle, L. S. and Huber, A. W. (1957) Residual stress and the compressive properties of steel - a summary report. Fritz Laboratory Reports, paper 46.

Batterman, R. H. dan Johston B. G. (1967) Behavior and Maximum Strength of Metal Columns. ResearchGate

Beer, H., and Schultz, G. (1970) "Theoretical Basis for the European Column Curves," Constr. Met., No. 3, p. 58.

Bjorhovde, R., and Tall, L. (1971) "Maximum Column Strength and the Multiple Column Curve Concept, ” Fritz Eng. Lab. Rep. No. 338.29, Lehigh University, Bethlehem, PA,

Bjorhovde, R. (1972) Residual stresses in thick welded plates, project summary report, May 1972. Fritz Laboratory Reports, paper 347.

Cook, R. D., Malkus, D. S., Plesha, M. E., dan Witt, R. J., (2002) Concept and Application of Finite Element Analysis. John Wiley \& Sons, Inc.

El-Sawy, K. M., Sweedan, M.I, Martini, M. I. (2009) Mayor Axis Elastic Buckling of Axial Loaded Castellated Steel Beam. Arab : Elsevier

Fukumoto, Y., Nethercot, D. A., and Galambos, T. V. (1983) "Experimental Data for the Buckling of Steel Structures-NDSS Stability of Metal Structures, ” Proc. 3rd Int. Colloq. SSRC, Toronto, Ontario, Canada, May, pp. 609-630.

Galambos,T.V. (1963) Inelastic lateral buckling of beams. Journal of the Structural Division ASCE, 89 (236).

Galambos, T. V. dan Surovek, A. E., (2008) Structural Stability of Steel: Concepts and Applications for Structural Engineers. John Wiley \& Sons, Inc.

Huber, A. W. and Beedle, L. S., (1952) Further Results on The Influence of Residual Stress on Column Strength. Fritz Laboratory Reports. 42.

Huber, A. W. and Beedle, L. S. (1954) Residual Stress and The Compressive Strength of Steel . Welding Journal, 33 (12), p. 589-s, Reprint No. 96 (54-3) Fritz Laboratory Reports.

Huber, A. W. (1956) Summary of Important Findings on Residual Stress and Compressive Properties of Rolled WF Columns, Lehigh University.

Huber, A. W. (1956) The Influence of Residual Stress on The Instability of Columns, Dissertation, Lehigh University. 
Kishima, V., Alpsten, G. A., and Tall, L. (1969) "Residual Stresses in Welded Shapes of Flame-Cut Plates in ASTM A572(50) Steel," Fritz Eng. Lab. Rep. No. 321.2, Lehigh University, Bethlehem, PA, June.

Logan, D. L. (2007) A First Course in Finite Element Method, 4th Edition. ISBN

McFalls, R. K., and Tall, L. (1970) "A Study of Welded Columns Manufactured from Flame-Cut Plates," AWS Weld. J., Vol. 49, No. 4, pp. 141s-153s.

Osgood, W. R. (1951) “The Effect of Residual Stress in Column Strength, ” Proc. First U.S. Natl. Congn. Appl. Mech., June, p. 415.

Yang, H., Beedle, L. S., and Johnston, B. G. (1952) "Residual Stress and the Yield Strength of Steel Beams, ”Weld. J. Res. Suppl., Vol. 31, pp. 224-225. 